Ines Kersan-Šskabić*

\title{
PUBLIC DEBT AND INTEREST RATE SPREAD IN THE EUROPEAN UNION
}

The goal of this paper is to assess the debt sustainability in the EU measuring the impact of public debt on the interest rate spreads. The results show that public debt has positive and significant influence on interest rate spreads but its influence is not the same for all observed groups of countries within the EU. The highest influence is in the Eurozone countries and in the group of peripheral EU countries (that are most affected by crisis: Portugal, Italy, Ireland, Greece and Spain). The lowest impact of public debt on interest rate spread is registered in non-Eurozone countries. Other important variables in explanation of interest rate spread are inflation differentials, FDI inflows, current account deficit and GDP growth rate.

Keywords: public debt, European Union, interest rate spread, panel data analysis

DOI: $10.15611 /$ aoe.2016.1.01

\section{INTRODUCTION}

The crisis years have opened a new set of issues that the developed countries have had to face. Usually the problems of indebtedness were and are related to the developing and the least developed countries, while the developed countries were on the other side of that problem, they were the creditors. But the huge amount of money that the governments of the developed countries have invested during the crisis years in the banking sector rescue and in the real economy has influenced their level of indebtedness. We have to differentiate between foreign (external) debt and public debt. The former includes not only the government debt but also debts of the other subjects (banks, enterprises from the private sector), while the public debt can be financed from the bonds issued in the foreign financial markets (the foreign part of public debt) and also in the domestic market. The problem of indebtedness has arisen in a number of EU member states in the aftermath of the global economic crisis. Almost all the EU countries have recorded an excessive budget deficit in recent years (higher than $3 \%$ of GDP) and the average public debt of the EU has risen from $62 \%$ of GDP in 2008 to $87.1 \%$ of GDP in 2013 (Eurostat, 2014). The most affected countries

\footnotetext{
* Faculty of Economics and Tourism, Juraj Dobrila University of Pula, Pula, Croatia
} 
are peripheral EU member states: Greece, Spain, Portugal, Ireland, and also Italy. They faced a huge increase of public debt and of total gross external debt that influence their (in)ability to borrow money in the international capital markets. Among the new EU member states we should highlight Hungary and Slovenia which joined the EU ten years ago, and Croatia which joined in 2013 and increased its public debt from 30\% of GDP in 2008 to $67 \%$ of GDP in 2013. Some of the countries (Croatia, Hungary) were also faced with a very high level of external debt. ${ }^{1}$

Here we arrive at the question: is there a problem of indebtedness in the EU member states and is this level of debt sustainable? In this paper we will focus on the debt problems of the EU member states, where we should differentiate between Eurozone members and non-Eurozone EU member states. As most of the EU countries (currently 18) are also members of the Eurozone, they are under specific rules (regulations) within the framework of Stability and Growth Pact and the European Fiscal Compact (Treaty on Stability, Coordination and Governance in the Economic and Monetary Union) which defined the fiscal discipline related to the level of public debt and budget deficit. We will continue our analysis with the focus on public debt $^{2}$. The question is: what should be analysed in the area of public debt? There are a few possibilities: the influence of public debt on the interest rate spread; the impact of public debt on economic development and the importance of public (foreign or domestic) debt structure (Dell'Erba et al., 2013; Snieska and Draksaite, 2013).

The aim of this paper is to analyze the sustainability of the level of public debt in EU countries with a focus on the determinants of debt sustainability. The sustainability will be measured with the interest rates spreads - the difference between a country's interest rate and the German long-term interest rates. We started with the hypothesis that the increase of public debt has an influence on the rise of interest rates and widens the gap between national interest rates and German interest rates (widens the interest rate

\footnotetext{
${ }^{1}$ The countries of Central and East Europe (CEE) were not so much affected by large share of debts in their GDPs, but they marked a strong growth (fast growth rates) of the public (and external) debt. All CEE countries are not in the same position, some countries have very small public debt (e.g. Estonia), but on the other hand Hungary and Slovenia faced very quickly growing public debt.

${ }_{2}$ Many countries issued $100 \%$ or almost all debt in their national currency; Estonia, Luxembourg, Austria, Finland and the United Kingdom issued $100 \%$ of their debt in their national currency, while this ratio was above $99 \%$ in France, Malta, Italy, Slovenia, Belgium and Spain. Only Lithuania, Croatia, Bulgaria, Romania, Hungary, Sweden, Poland and Latvia issued less than $80 \%$ of their debt in their national currency.
} 
spread). The German interest rates are chosen as the benchmark because of their stability. The average yield spread of ten year bonds against Germany was a narrow 15 basis points between the introduction of the euro in 1999 and late August 2008, increasing by more than the factor of five to almost 80 basis points between September 2008 and February 2009. At their peak, the Irish and Greek government bonds even traded more than 250 basis points above the German rates (Attinasi et al., 2009) ${ }^{3}$. This is connected with the positive macroeconomic perspective in Germany: a surplus in the current account, sound public finance, industrial leadership, etc. Beirne and Fratzscher (2013) warn about the overpricing of actual yields in Eurozone peripheral countries while for core countries it is underpriced in comparison with the pre-crisis period. Because of these huge changes (fluctuations) in interest rates it will be more reliable to include the spreads of the country's interest rates towards the German (rather than nominal) interest rates.

The topic of public debt sustainability is interesting in the EU because it is one of the nominal convergence criteria (threshold of $60 \%$ of GDP) that countries which want to join the economic and monetary union (EMU) should fulfil. When the EMU project started in 1999 the majority of EMU satisfied these criteria, while just Italy and Belgium had excessive public debt. During the period of economic growth (the 2000s before the crisis) the majority of EU member states had smoothly increased their public spending that was on the one hand necessary for EMU members (because they sacrificed their national monetary policies and they needed more money to react in the market), and for others, public spending was one way of boosting economic growth (especially in peripheral EU countries). The necessity for public resources strongly increased during the financial crisis of 2008-2009 when many countries intervened in the financial sector but also more money was needed for social security - in general for rescuing their economies. The results of these interventions was that in 2013, sixteen countries had excessive public debt and also some countries faced the inability of servicing their debts (Greece and Portugal in 2010, Ireland in 2011) and asked the EU for financial help. The EU provided financial help but also made efforts to help these countries through focusing them on the productivity increase that

\footnotetext{
${ }^{3}$ The long term interest rates in Germany decreased from $5.26 \%$ in 2000 to $4.22 \%$ in 2008 , and further to $1.57 \%$ in 2013. At the same time the Greek interest rates increased from 6.10 to $10.05 \%$ : Portugese interest rates were reduced from 5.59 in 2000 to $3.75 \%$ in 2013 . The peak interest rates were in Greece and Portugal in 2012 (22.5\% and $10.55 \%$ respectively), in Ireland in $2011(9.60 \%)$, but also in new member states: Latvia and Lithuania in 2009 $(12.36 \%$ and $14.0 \%$ respectively).
} 
should result in the rise of their competitiveness and reduction of current account deficit. Additionally, the EU issued strong recommendations to reduce the budget deficit as a generator of the future level of public debt.

We will apply the statistic and dynamic econometric tools of panel data analysis which is suitable as we deal with a cross-sectional and a longitudinal dimension. The rest of the paper is organized as follows: the second section contains the literature review, the third is focused on the research (data, methodology and results) and the last one concludes with policy implications.

The contribution of this paper is in its comprehensive approach towards measuring debt sustainability in the EU stressing the difference between Eurozone and non-Eurozone member states; new member states and the group of countries most affected by the crisis (Portugal, Italy, Ireland, Greece and Spain) ${ }^{4}$. The data cover the period from 2002 which means that the monetary union in a large part of the EU has already been in operation.

\section{LITERATURE REVIEW}

The debt problem usually appears in the literature dealing with developing countries which are faced with an overhang in debt (Krugman, 1988). Borrowing abroad is an important channel towards the realization of investments and the creation of a prerequisite for economic growth. But when the borrowing started to increase very fast and its level has been continuously rising (as a share of GDP) then the danger for the solvency arises. A big debt can become the opposite of the first idea - it can be a burden on further economic development, and sacrificing growth (in the short and long run) can be very costly for any country. In the short-term governments are able, through borrowing in domestic and foreign markets, to provide funds for large investment projects, increasing the wages in public sector, etc. which as a consequence pushes up the domestic demand and consumption. This has a positive impact on domestic production and consumption. ${ }^{5}$ Apparently the situation seems to be good, but policymakers do seem to think that debt reduces long-term economic growth (Reinhart and Rogoff, 2010a,b; Kumar and Woo, 2010; Checherita and Rother, 2010; Cecchetti, Mohanty and Zampolli, 2011) ${ }^{6}$.

\footnotetext{
${ }^{4}$ The level of public debt in GDP in 2013: Portugal 129\%, Italy 132\%, Ireland 123\%, Greece $175 \%$ and Spain $94 \%$.

${ }^{5}$ But also on imports.

${ }^{6}$ The correlation becomes particularly strong when public debt approaches 100 percent of GDP
} 
The question of debt sustainability can be applied to the external debt or to the public debt. The external debt is usually linked with the current account (deficit) and the public debt with a primary balance.

The indicators of (public) debt sustainability are connected with the government behaviour (spending): when the government spends money to create long-term added values (which can give results not only to us but also to future generations); when the rate of return on investment is higher than the interest rate that should be paid; when the ratio of debt to GDP is stable or decreasing over time; when it is acceptable for internal and external creditors; the ability of government to maintain sustainable debt. In a situation when the debt is growing faster than the ability of the countries to service their debt, it is unsustainable. The level of debt can be defined as "sustainable" if the main macroeconomic indicators of the country remain stable or show economic growth over the long run (Rankin and Roffia, 1999). Two general approaches to debt sustainability analysis have been pursued beside other theoretical and empirical models. The first one focuses on financial sustainability (a borrower based approach) - it is possible to run a sustainable fiscal deficit as long as the growth rate of the economy is higher than the interest rate, which will in turn ensure the stability of debt-toGDP ratio (Cuddington, 1996). The second approach evaluates if there is a present value borrowing constraint that could limit the quantities to borrow (Gupta, 1992). ${ }^{7}$ This approach is applied in assessing the debt sustainability for the developing and least developed countries.

The IMF provides their definition of debt sustainability: a debt "is sustainable if it satisfies the solvency condition without a major correction (...) given the costs of financing" (Wyplosz, 2007). Various government debt sustainability assessment methodologies are considered by Afonso et al. (2012), Aspromourgas et al. (2010), Faraglia et al. (2013), Teica (2012),

\footnotetext{
${ }^{7}$ This concept has been extensively used by the IMF and World Bank in recent years. The concept has been outlined as a group of indicators with specified thresholds. The World Bank has developed The Country Policy and Institutional Assessment (CPIA), together with the International Monetary Fund (IMF)'s Debt Sustainability Framework (DSF). The DSF is a standardized framework for conducting debt sustainability analysis (DSA) in low-income countries. It consists of an analysis of the country's projected debt burden over the next 20 years and its vulnerability to shocks and an assessment of the risk of debt distress. Berg et al. pointed out that the WCA is biased it produces too many false alarms for each missed crisis, when evaluated in terms of the loss function that is used in the DSF to justify the individual debt burden thresholds. Wyplosz (2007) warns that any debt sustainability assessment is only valid within the bounds of the underlying guesses.
} 
Choi et al. (2010), Frank and Ley (2009), Neck and Sturm (2009), Sopek (2009), Genberg and Sulstarova (2008), Wyplosz (2007), Telatar et al. (2004), Uctum and Wickens (2000). Wyplosz (2007) criticizes the IMF approach pointing out that there is no model/formula that can incorporate all the facts and some of them can not be predictable. He warns that it is important to see the revenue side (GDP, export, other revenues) and that there is no uniform rule to be applied for all countries. Gros and Alcidi (2011) point out the importance of foreign debt, not just domestic (public) debt, in analyzing the effects of monetary union. "Given the dependency on foreign capital of many Eurozone peripheral countries, external debt is of crucial importance. In what follows we shall argue that fiscal adjustment alone is not sufficient if it is not accompanied by external adjustment" (Gros and Alcidi, 2011).

Snieska and Draksaite (2013) gave a critical overview of the criteria of an assessment of public debt sustainability. They focus on the evaluation in the case of small countries and warn about the complexity (high borrowing risk - vulnerability to the stochastic changes of the global economy and international borrowing markets).

What level of public debt is (un)sustainable? There are some highly developed countries that have a very high level of public debt, i.e. Japan (debt-to-GDP ratio is more than 200\%) - which is the highest among the developed countries. Nevertheless, Japan's long-term government bond yields have been low and stable; this seems to be "an important puzzle" (Krugman and Eggertsson, 2011).

The literature mainly suggests two channels through which fiscal conditions influence long-term interest rates: crowding out and default risk. Through the first channel, greater government funding leads to a smaller fund supply for private agents, which results in a higher long-term interest rate. Through the second channel, as fiscal conditions are more strained, the probability of government default is higher and investors require a larger premium to compensate for the risk, which leads to a higher interest rate (Ichiue and Shimizu, 2012).

The role of the interest rate in public debt sustainability analysis has been researched by Domar (1944) and Pasinetti (1997), who derive three possible cases for the relationship between the rate of interest $(i)$ and the growth rate of output ( $g$ ): if $g>i, d$ will tend to zero; if $g=i, d$ will remain constant and, finally, if $g<i, d$ keeps growing constantly. Clearly, in Pasinetti's view, the rate of interest is the key variable to determine both the evolution of $d$ and the tax that must be imposed "in order to pay for the interest", thus 
keeping $d$ constant. De Grauwe and Ji (2013) find that the level of public debt is significantly correlated with long-term sovereign spreads in the Eurozone, but that debt ratios have no statistically significant impact on sovereign spreads in standalone countries. Roubini (2001) gave a few approaches at debt sustainability assessment and the non-increasing ratio of foreign debt in GDP (one practical criterion of sustainability) and also discussed "permanent" rather than "current" primary gaps and the resource/trade balance gap, and warns that in a situation of negative GDP growth rate and positive and high interest rates on debt, one can observe a current gap. The stabilization of debt/GDP ratio is sometimes hard to achieve (trade balance in deficit or not enough surplus; reduction of consumption and investment).

Aizenman, Jinjarak, and Park (2013) analyzed the determinants of market spreads and find quite different results for pre-crisis, crisis and post-crisis years. The most important determinants of emerging market spreads in the pre-crisis periods (2004-07) were trade openness and state fragility; in the crisis period (2008-09) inflation and the external debt ratio, and in the postcrisis periods (2010-12) the main drivers of spreads were public debt and inflation. Barrios et al. (2009) and the IMF (2010) find that public debt and external debt are important predictors for CDS spreads. Greenlaw, Hamilton, Hooper, and Mishkin (2013) conducted an analysis of 20 advanced economies for the period 2000-10 and found that a 10 percentage point increase in the debt-to- GDP ratio is associated with a 45 basis point increase in sovereign yields. Alper and Forni (2011) applied different samples and methodologies, found that a 10 percentage point increase in the debt-to-GDP ratio is associated with an increase in long-term yields that ranges between 10 and 70 basis points. Ichiue and Shimizu (2012) found that a 10 point increase in public debt is associated with a 13-16 basis point increase in long-term yields. They also commented on the trend of interest rate movement - from introducing the euro to the beginning of the European debt problem, the long-term interest rates of peripheral countries converged to those of Germany (where they were mispriced). Kinoshita (2006) develops a theoretical model linking government bond yields to government debt and tests its predictions using a panel of 19 advanced economies. The results suggest that a 1 percentage point increase in the government debt-to-GDP ratio raises the real long-term government bond yield by about $2-5$ basis points. This impact is comparable to the 3-5 basis point effect found in Laubach (2009) and Engen and Hubbard (2004) for the U.S. Poghosyan (2012) found that in the long run, government bond yields increase by about 
2 basis points in response to a 1 percentage point increase in government debt-to-GDP ratio and by about 45 basis points in response to a 1 percentage point increase in the potential growth rate. Attinasi et al. (2009) find that higher expected budget deficits and/or higher government debt ratios relative to Germany contributed to higher government bond yield spreads in the euro area during the crisis years (2007-09). They did not find a statistically significant effect of the amount of resources committed by the governments for the purpose of stabilizing the banking sector on sovereign bond spreads. Gerlach et al. (2010) analyzed the determinants of sovereign bond spreads in the euro area where the main emphasis they give to the aggregate risk factor as well as on the size and structure of a country's banking sector, but also found that government debt levels and forecasts of future fiscal deficits are significant determinants of sovereign spreads. Steinkamp and Westermann (2012) contributed to the debate about the sovereign bond market including the share of senior lenders (IMF, ECB, EFSF) in the total outstanding government debt. They found a close relationship between senior tranche lending and recent developments in the sovereign bond market.

Dell'Erba et al. (2013) investigated the debt structure, debt level and sovereign spreads in emerging and advanced countries and found that there is a significant correlation between spreads and debt levels in emerging market countries and in advanced countries, but in the latter the strength of correlation is about one fifth of that found in emerging market economies. For Eurozone countries the correlation between spreads and debt ratios is similar to that of emerging market countries. Because they suffer from "original sin" - their central banks (although they exist) are not domestic lenders of last resort that can rule out self-fulfilling liquidity crises - and the result is that their government bond markets are more fragile and more susceptible to self-fulfilling liquidity crises than those of standalone countries (Corsetti, 2010; De Grauwe, 2011; Eichengreen and Hausmann, 1999). ${ }^{8}$

Drakšaite (2011) warns that an assessment of government debt sustainability in a stochastic economy requires focusing on the analysis of the contingency of the economy.

\footnotetext{
8 "Original sin" was first used in an economic sense in 1999 when economists Barry Eichengreen and Ricardo Hausmann described the developing world's inability to borrow abroad in their local currency the "original sin" of emerging markets. Original sin is a pernicious phenomenon. Borrowing in foreign currencies can both trigger and exacerbate financial and economic crises. When a country's debts are denominated in foreign currencies, it often forces policy makers to keep exchange rates pegged or heavily managed.
} 


\section{RESEARCH}

\subsection{Data and methodology}

We have performed an analysis of distress of EU economies by measuring the dependence of long-term interest rate spread (the difference between interest rates in EU member states and German interest rates) on the level of public debt (share in GDP), FDI inflows (share in GDP), current account (share in GDP), inflation differentials (toward German inflation rate) and GDP growth rates. We have made an analysis for the whole EU, then for Eurozone member states and for new EU member states separately. ${ }^{9}$

The annual data are from the Eurostat database and WIIW (2013) and cover the period from 2002 to 2013 . Considering that the sample has a cross-sectional dimension, represented by countries $(i=1, \ldots, N)$ and a longitudinal dimension, represented by a time series $(t=1, \ldots, T$ periods $)$, the panel data method is used. The sample comprises unbalanced panel data, that is, there are some periods missing from some units in the population of interest. Panel data analysis can be static (fixed and random effects) and dynamic (Wooldrige, 2002; Hsiao, 2003; Verbeek, 2008). We will provide both types of analysis. The panel data studies typically employ the fixed effects specification, where fiscal variables (the debt-to-GDP ratio) are introduced along with other control variables (including GDP growth) as long-term determinants of sovereign borrowing costs. Most of the studies do not distinguish between long-term and short-term effects of sovereign bond yield determinants and focus only on the long-term association between bond yields and fundamental factors (Poghosyan, 2012).

The random effects and fixed effects estimation methods deal with the problem of non-observed heterogeneity. Fixed effects models capture country-specific effects with $\alpha_{i}$, that do not change over time, and random effects incorporate heterogeneity among the countries by including a specific non-observable effect $\left(\varepsilon_{i t}\right)$ in the error term.

Although these are the estimation methods most commonly employed with panel data, their estimates are consistent only if the condition of strict exogeneity of regressors applies which will be verified by the methodology proposed by Wooldridge (2002). The Hausman test indicates that fixed effects models are more suitable than random effects. In testing the validity of models we found that fixed effect models suffer from problems of

\footnotetext{
${ }^{9}$ For fiscal conditions, stock variables have greater explanatory power than a flow variable (primary balance) and because of this we chose the public debt rather than budget deficit.
} 
heteroskedasticity so we corrected them with cluster-robust standard errors (the vce (robust) option).

We started with the static panel data analysis where the corrected models (for heteroskedasticity and/or autocorrelation) are presented.

$$
I N T S_{i t}=\alpha+\beta P D G D P_{i t}+\gamma_{1} X_{1, i t}+\ldots+\gamma_{n} X_{n, i t}+\varepsilon_{i t}
$$

where INTS is interest rate spread; $P D G D P$ is public debt in \% of GDP and $X_{j, i t}$ are a set of $n$ independent variables: current account deficit (\% of GDP); FDI net inflows (as a share in GDP); inflation differentials (difference against the German interest rate) and GDP growth rate (in \%, annual growth rate). We expected the positive influence of all these variables on the interest rate spread, except for the GDP growth rate.

We continued with the dynamic (GMM) panel data to overcome the limitations of static panel analysis (Arellano and Bond, 2001). The application of dynamic models is driven by the nature of the relation that we investigate and the dynamic aspects of their adjustment. Estimation with the dynamic model allows the dynamics of the underlying processes, which can be crucial in obtaining consistent estimates of the remaining parameters (Bond, 2002). Turning the lagged dependent variable, except that which alleviates rigidity in the adjustment, also reduces the problem of omitted variables. The dynamic model is defined in the following form:

$$
\begin{aligned}
Y_{i t} & =\delta Y_{i t-1}+\lambda \mathbf{X}_{i t}+\varepsilon_{i t} \\
\varepsilon_{i t} & =\eta_{i}+\gamma_{t}+u_{i t}
\end{aligned}
$$

where $Y_{i t}$ refers to the dependent variable (that is also included with time lags), $\mathbf{X}_{\text {it }}$ is the vector of independent variables for country $i$ at time $t$, and $\varepsilon_{i t}$ is the error term that includes country- and time-specific attributes. The model is estimated using System GMM developed by Arellano and Bover (1995) and Blundell and Bond (1998), with the user-written xtabond2 command implemented in Stata 12 (Roodman, 2009).

To find out if there is bidirectional causality between public debt and interest rate spread we employed the Granger causality test. The Grangercausality testing methodology seems to be an ideal tool to examine the different sets of predictions about parameter signs empirically. According to Granger's definition of causality, a stationary time series $Y_{t}$ is said to 'cause' another stationary time series $X_{t}$ if the inclusion of past values of $Y_{t}$ significantly reduces the predictive error variance of $X_{t}$. In econometric 
practice, Granger-causality tests are carried out by regressing $X_{t}$ on its own lags and on lags of $Y_{t}$. If the lags of $Y_{t}$ are found to be jointly statistically significant, then the null hypothesis that $Y_{t}$ does not Granger-cause $X_{t}$ can be rejected. The test of whether $x$ Granger-causes $y$ consists of a test of the hypothesis that $\beta_{1}=\beta_{2}=\ldots=\beta_{n}$ are equal to zero (the Wald test) after controlling for $y^{6} \mathrm{~s}$ own lags and the influence of additional controls $(z)$.

\subsection{Results}

From Table 1 it is obvious that the influence of public debt on the interest rate spreads differs among the data for the whole EU, Eurozone and nonEurozone countries. A high influence was found in the EU where the increase of share of public debt in GDP of $1 \%$ will increase the interest rate spreads from 5.2 basis points (if we take more variables in the analysiscolumn 7) to 7.6 basis points (if we consider only the influence of public debt - column 2). The data for the influence of public debt on interest rate spreads for Eurozone vary from 6.7 to 8.8 basis points. The range of influence of public debt on interest rate spreads becomes reduced when we include more variables. Here we can point out that the current account deficit, FDI inflows and inflation differentials have also a positive and significant impact on the level of interest rate spreads, in line with the economic theory and our expectation. If the current account increases, the interest rate spread will also increase because of the deterioration of the trade balance which may cause the need for additional borrowing. FDI inflows increase the external vulnerability and exposure to the contagion effect of foreign disturbances and turbulences. Inflation and interest rate are connected through the Fisher effect, and they move in the same direction. ${ }^{10}$ The GDP growth rate has a negative impact on interest rate spreads which is logical - if the GDP is growing it shows the positive prospects of one economy and the economic policy is perceived as more transparent and reliable in the creditor's eyes, so the borrowing becomes cheaper.

The situation is quite different in non-Eurozone countries where public debt does not have a significant impact on the interest rate spread and the main determinants are current account, FDI inflows and inflation differentials, while the GDP growth rate still has a negative impact on interest rate spreads. The level of public debt (share in GDP) in non-

\footnotetext{
${ }^{10}$ The Fisher effect connects the nominal (and real) interest rate with inflation. An increase in inflation will result in an increase in the nominal interest rate.
} 


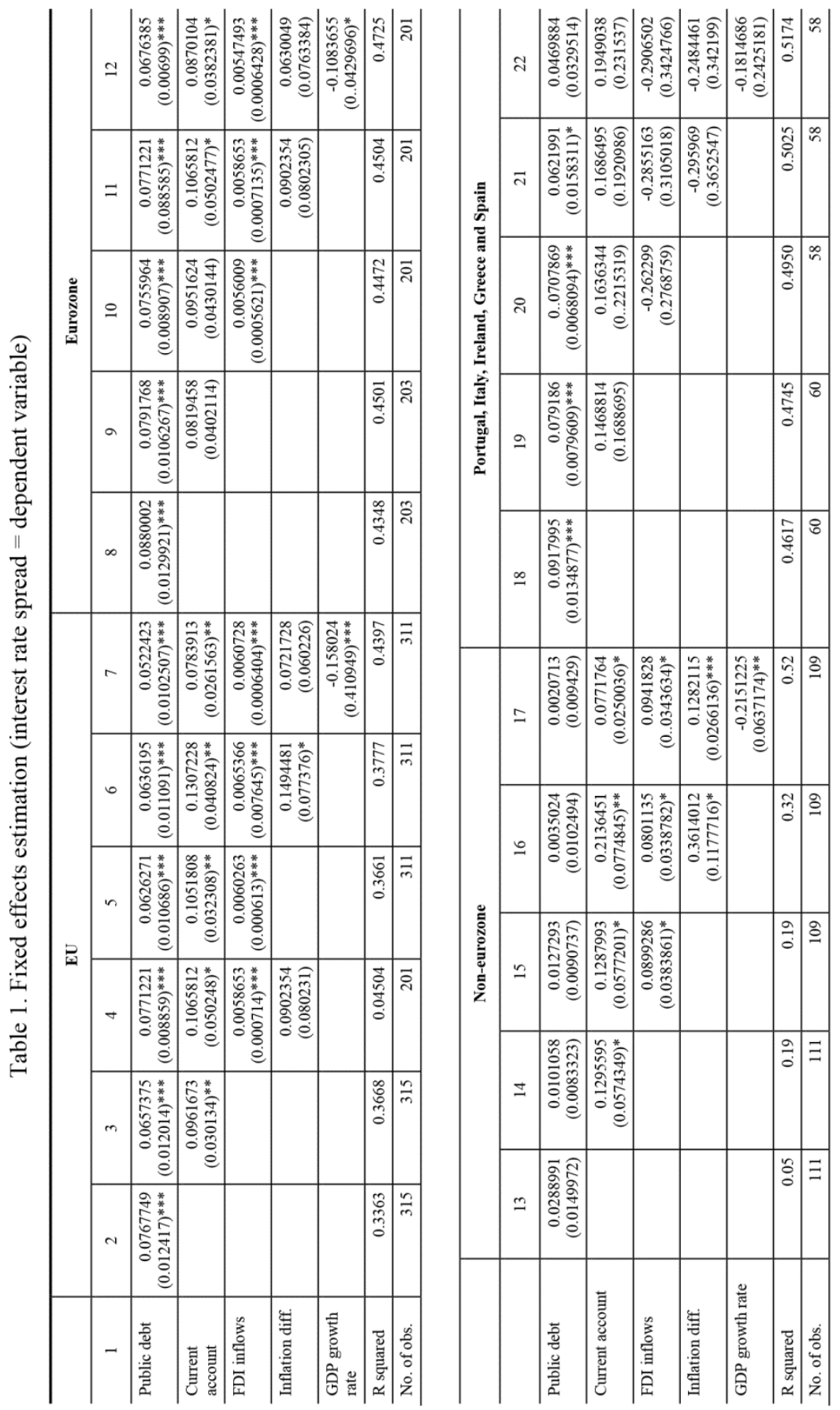




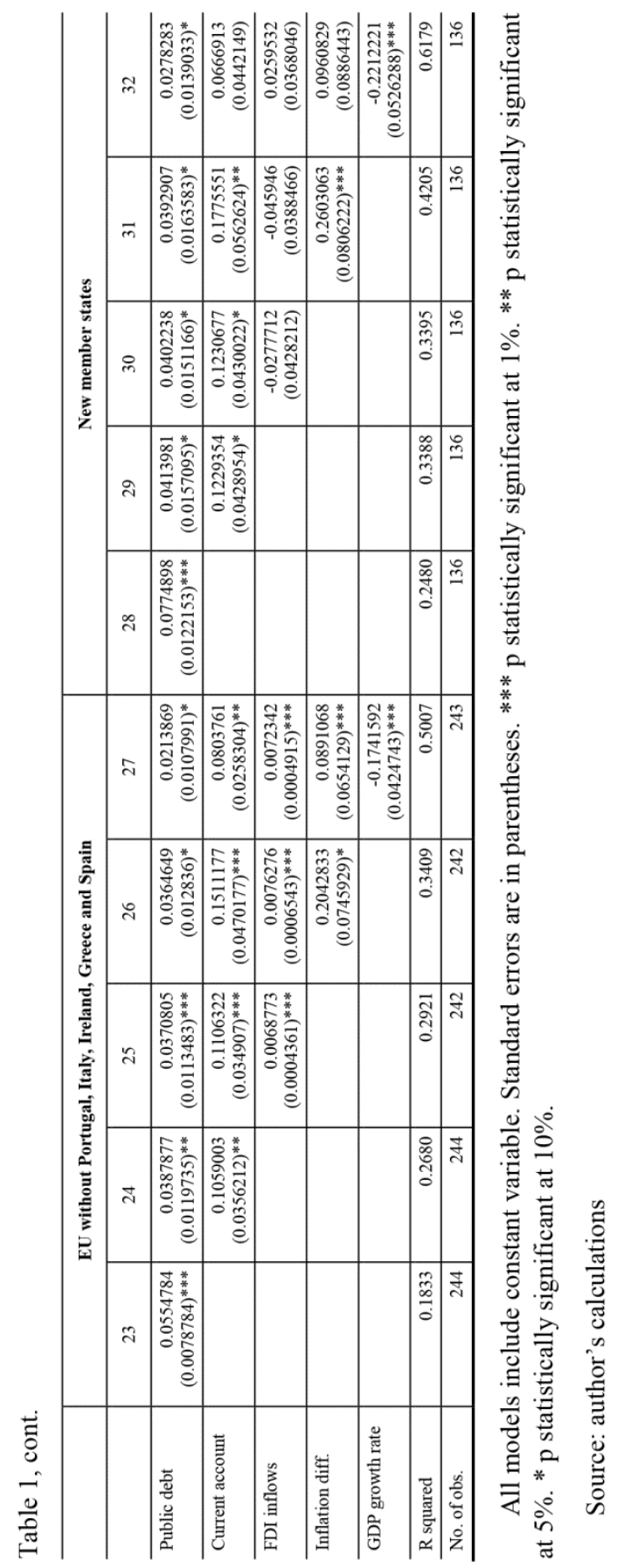




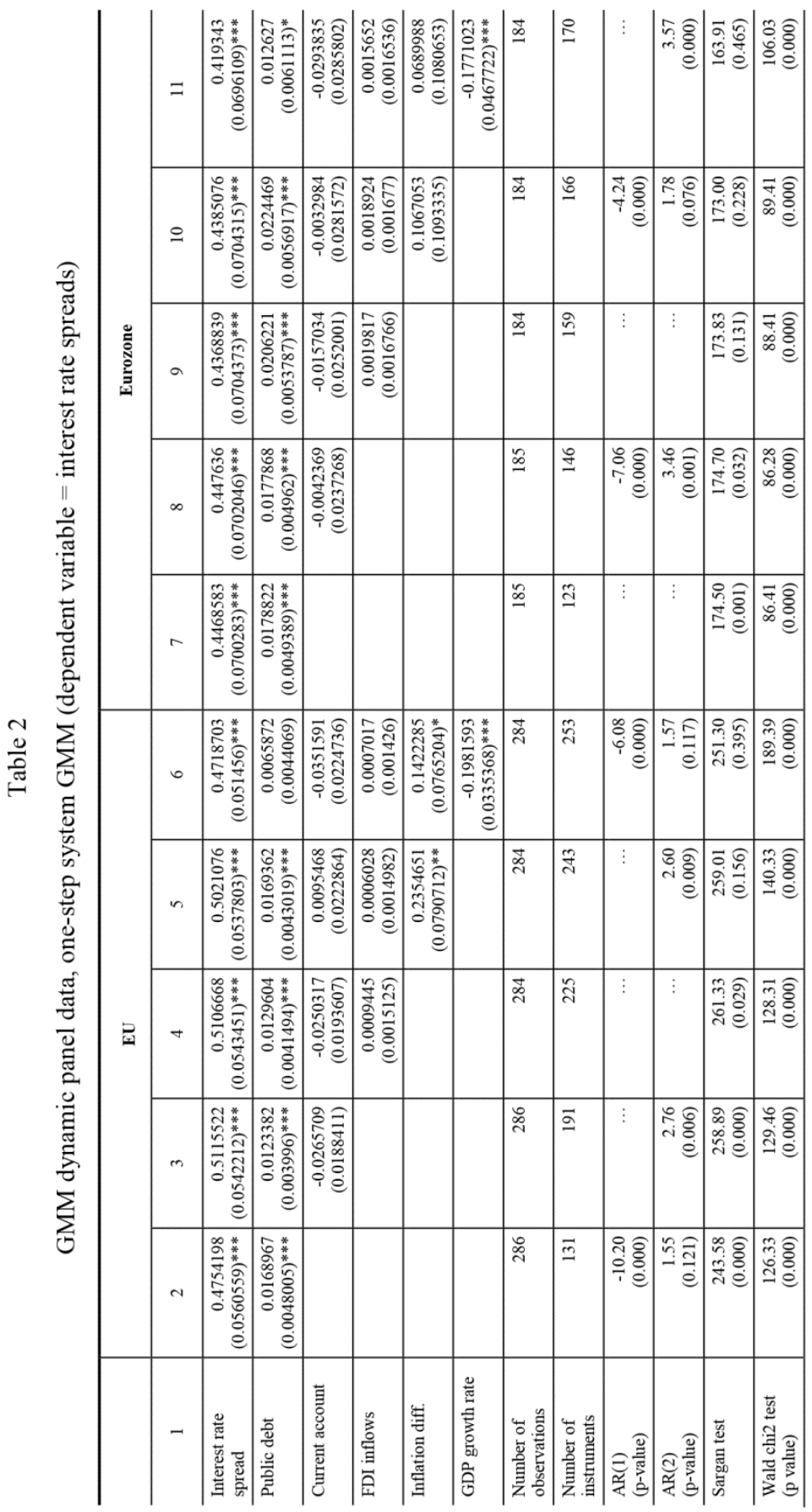




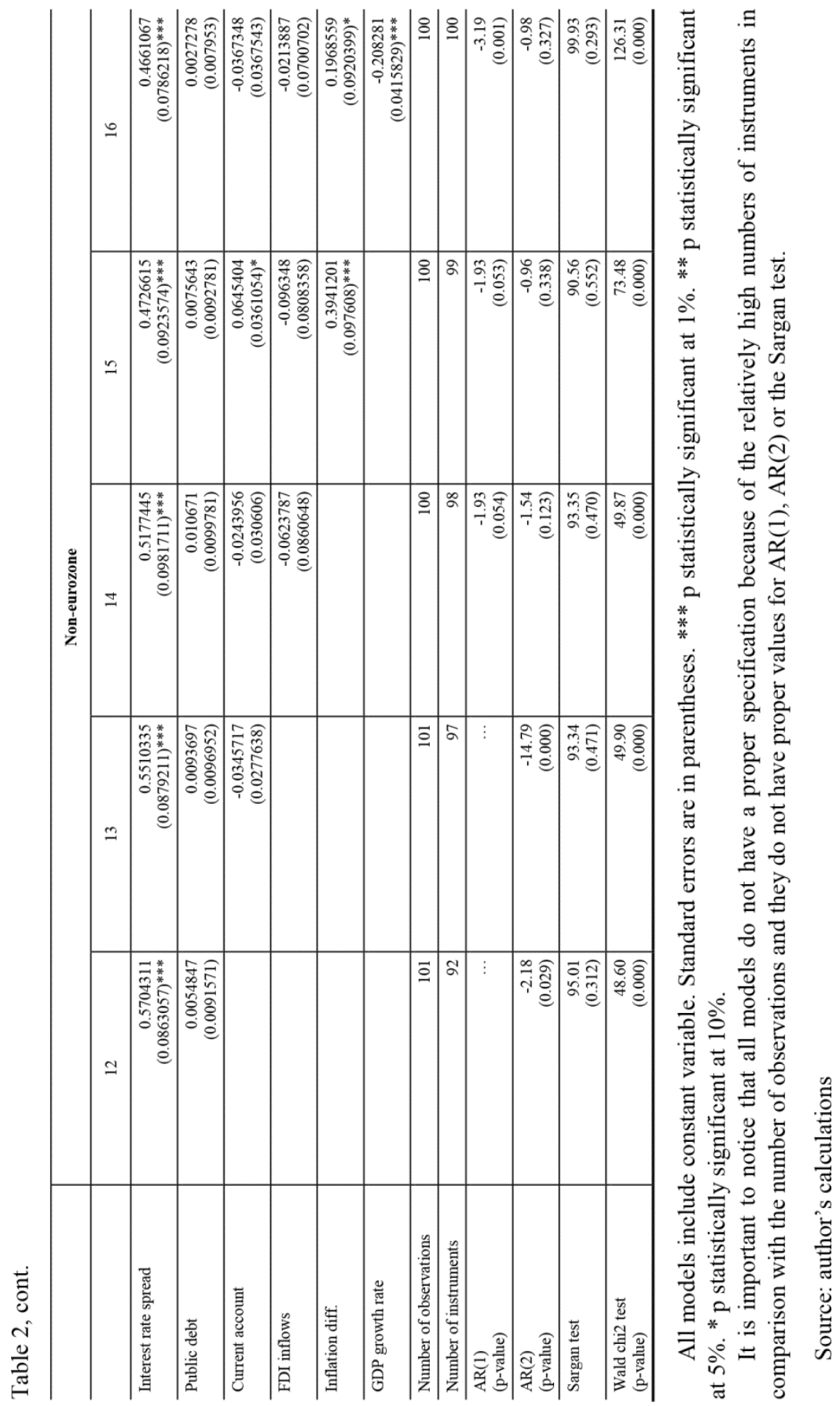


Eurozone EU member states is in the range from $18.5 \%$ in Bulgaria to $80 \%$ in Hungary and $90 \%$ in the UK. But the models in columns $13-16$ have low $\mathrm{R}$-squared which indicates that in this group of countries the chosen variables explain only partially the interest rate spreads. As many of the nonEurozone countries are from Central and Eastern Europe, there are other determinants connected with the institutional and market development that can also be included in the explanation of interest rate differentials.

If we separate the group of EU countries that have been most affected by the crisis (the so called PIIGS group, i.e. Portugal, Ireland, Italy, Greece and Spain) we find a higher impact of public debt on the interest rate spread (from 6 to 9 basis points) but also the unimportance of other exogenous variables. The rest of the EU member states in that case will have an influence of public debt on interest rate spread in the range from 2.1 to 5.5, which is lower in comparison with the whole EU and with the most affected countries. If we make an analysis on the sample of the 13 new EU member states (Table 1, columns 28-32) then we find the influence on public debt on interest rate spread to be between 3.9 and 7.7 basis points.

We have tested the models for robustness by excluding Germany from the sample (because Germany is the benchmark for calculating interest rate spread and inflation spread) and by introducing the dummy variables for crisis (value 1 for crisis years 2008 and 2009 - recession in Europe and value 0 for other years). In both cases the influence of public debt on the interest rate spread varies between 5.1 and 7.7 for the EU. Hence the results remain almost the same. We have also conducted the analysis for the Eurozone countries using the interest rates (EMU convergence criteria) as a dependent variable to see the changes in the results. In this case the sign of the impact of the analyzed variables remained as we expected, but their influence is weaker and some models do not fit the diagnosis test. Regarding the already mentioned huge differences in interest rates from 2008 onward, we think that the models with interest rates spread are more appropriate ${ }^{11}$.

We found that fixed effects models suffer from an endogeneity problem and many authors warn that debt is likely to be endogenous. There are different ways to address endogeneity: by using lagged values of the debt-toGDP ratio (Cecchetti, Mohanty and Zampolli, 2011), GMM estimations with internal instruments (Kumar and Woo, 2010; Presbitero, 2012), and by instrumenting the debt-to-GDP ratio with the average debt of partner countries (Checherita and Rother, 2010).

\footnotetext{
${ }^{11}$ The results are available on request.
} 
The dynamic analysis was performed for three groups of countries: the EU, Eurozone and non-Eurozone countries. The results are in Table 2.

The dynamic analysis shows the lower influence of public debt (share in GDP) on interest rate spreads that go from 0.6 to 1.7 basis points in the EU and from 1.2 to 2.2 in the Eurozone. The highest influence has arrived from the interest rate spreads from previous period which explains more than the 40 basis points of interest rate spreads. In these models, current account deficit and FDI inflows are not significant; the significance of inflation differentials is growing from 6.9 basis points (in Eurozone) to 23 basis points in the EU. GDP growth rate has a negative and significant impact of 17 (in the Eurozone) to 19 (in the EU) basis points. Regarding the nonEurozone countries, the dynamic analysis has confirmed the earlier results public debt is not a significant determinant of interest rate spreads. The only significant variables are the lag of interest rate spreads, inflation differentials and GDP growth rate, all with the expected sign.

Given that public debt and interest rate spreads are the focus of the research, we have expanded our analysis with the Granger tests. Table 3 provides the results for three equations examining the causality among public debt and interest rate spread (dependent variable) for three groups of countries: the Eurozone, the EU and the non-Eurozone. To test for panel causality, the most widely used method in the literature is that proposed by Holtz-Eakin et al. (1988). They suggest that the lag length should be less than one-third of the total time period to avoid the over-identification problem. Therefore, we decided to use two lags. For lagged dependent variables, one lag for levels and difference equations is used, where for endogenous variable we used two lags for level and difference equation. The Hansen test detected validity of instruments for the Eurozone and the EU, while instruments for the non-Eurozone were identified as invalid. The Arellano-Bond test for first and second order autocorrelation is satisfactory for the non-Eurozone and the EU. Public debt with a one- and two-year lag has a significant impact on the interest rate spread but the sign of impact changes, so a one-lag public debt in the Eurozone and in the EU has a positive impact on the interest rate spread while a two-lag public debt has a negative impact in these groups of countries. This indicates that an increase in public debt in the previous year has an influence on the increase of interest rate spread. In the non-Eurozone, the two-lag of public debt has a positive impact on the interest rate spread and one-lag has a negative influence, but the model fails the Hansen J-test. 
Table 3

Granger causality - interest rate spread (dependent variable)

\begin{tabular}{|c|c|c|c|}
\hline & Eurozone & Non-eurozone & $\mathbf{E U}$ \\
\hline Explanatory variables & \multicolumn{3}{|c|}{ Coefficients } \\
\hline $\begin{array}{l}\text { 1-lag interest rate spread } \\
\text { (standard deviation in parentheses) }\end{array}$ & $\begin{array}{l}0.3236822 \\
(0.0792191)^{* * *}\end{array}$ & $\begin{array}{l}0.4729186 \\
(0.1045853)^{* * *}\end{array}$ & $\begin{array}{l}0.3557842 \\
(0.0679344)^{* * *}\end{array}$ \\
\hline 2-lag interest rate spread & $\begin{array}{l}0.1805186 \\
(0.1088825)^{*}\end{array}$ & $\begin{array}{l}0.2033836 \\
(0.1070385) * * *\end{array}$ & $\begin{array}{l}0.1943542 \\
(0.0850457)^{* *}\end{array}$ \\
\hline Public debt & $\begin{array}{l}-0.0109382 \\
(0.029451) \\
\end{array}$ & $\begin{array}{l}0.2132743 \\
(0.0481699) * * * \\
\end{array}$ & \begin{tabular}{|l|l|}
0.0082417 \\
$(0.0307847)$ \\
\end{tabular} \\
\hline 1-lag public debt & $\begin{array}{l}0.190877 \\
(0.050861)^{* * *}\end{array}$ & $\begin{array}{l}-0.3736939 \\
(0.0873627)^{* * *}\end{array}$ & $\begin{array}{l}0.1162397 \\
(0.0520374)^{* *}\end{array}$ \\
\hline 2-lag public debt & $\begin{array}{l}-0.1705599 \\
(0.0296662)^{* * *}\end{array}$ & $\begin{array}{l}0.1651793 \\
(0.0525684) * * *\end{array}$ & $\begin{array}{l}-0.1193178 \\
(0.0283317)^{* * *}\end{array}$ \\
\hline No. of observations & 167 & 91 & 258 \\
\hline No. of groups & 17 & 10 & 27 \\
\hline No. of instruments & 120 & 88 & 133 \\
\hline $\begin{array}{l}\text { Arellano-Bond test for AR(1) in first } \\
\text { differences } \\
\text { H0: There is no first-order serial } \\
\text { correlation in residuals }\end{array}$ & $\ldots$ & $\begin{array}{l}-2.58 \\
(0.01)\end{array}$ & $\begin{array}{l}-6.21 \\
(0.000)\end{array}$ \\
\hline $\begin{array}{l}\text { Arellano-Bond test for } \mathrm{AR}(2) \text { in first } \\
\text { differences } \\
\text { H0: There is no second-order serial } \\
\text { correlation in residuals }\end{array}$ & $\ldots$ & $\begin{array}{l}-1.66 \\
(0.097)\end{array}$ & $\begin{array}{l}-2.69 \\
(0.007)\end{array}$ \\
\hline $\begin{array}{l}\text { Hansen J-test of overidentifying } \\
\text { restrictions } \\
\text { H0: Model specification is correct and } \\
\text { all overidentifying restrictions (all } \\
\text { overidentified instruments) are correct } \\
\text { (exogenous) } \\
\text { (p-value in parentheses) }\end{array}$ & $\begin{array}{l}149.80 \\
(0.014)\end{array}$ & $\begin{array}{l}80.89 \\
(0.514)\end{array}$ & $\begin{array}{l}203.39 \\
(0.000)\end{array}$ \\
\hline $\begin{array}{l}\text { Difference-in-Hansen tests of } \\
\text { exogeneity of GMM instrument } \\
\text { subsets: } \\
\text { Hansen test excluding SGMM } \\
\text { instruments (i.e. the differenced } \\
\text { instruments) } \\
\text { H0: GMM differenced instruments are } \\
\text { exogenous }\end{array}$ & $\begin{array}{l}112.93 \\
(0.051)\end{array}$ & $\begin{array}{l}50.94 \\
(0.862)\end{array}$ & $\begin{array}{l}119.76 \\
(0.0087)\end{array}$ \\
\hline WALD test & $\begin{array}{l}144.77 \\
(0.000)\end{array}$ & $\begin{array}{l}70.51 \\
(0.000)\end{array}$ & $\begin{array}{l}153.78 \\
(0.000)\end{array}$ \\
\hline
\end{tabular}

Source: author's calculations 
Table 4

Granger causality - public debt (dependent variable)

\begin{tabular}{|c|c|c|c|}
\hline & Eurozone & Non-eurozone & $\mathbf{E U}$ \\
\hline Explanatory variables & \multicolumn{3}{|c|}{ Coefficients } \\
\hline $\begin{array}{l}\text { Lag public debt } \\
\text { (standard deviation in parentheses) }\end{array}$ & \begin{tabular}{|l|}
1.519428 \\
$(0.0811045)^{* * * *}$
\end{tabular} & \begin{tabular}{|l|}
1.625728 \\
$(0.0823192) * * *$
\end{tabular} & $\begin{array}{l}1.520506 \\
(0.0616528)^{* * *}\end{array}$ \\
\hline 2-lag public debt & $\begin{array}{l}-0.5264634 \\
(0.0814911)^{* * *}\end{array}$ & $\begin{array}{l}-0.6526706 \\
(0.0854078)^{* * *}\end{array}$ & $\begin{array}{l}-0.5152275 \\
(0.0639709)^{* * *}\end{array}$ \\
\hline Interest rate spread & $\begin{array}{l}-0.841049 \\
(0.2304917)\end{array}$ & $\begin{array}{l}0.9146802 \\
(0.1968759)^{* * *}\end{array}$ & $\begin{array}{l}0.0453086 \\
(0.1799313)\end{array}$ \\
\hline 1-lag interest rate spread & $\begin{array}{l}1.086426 \\
(0.2177151)^{* * *}\end{array}$ & $\begin{array}{l}-0.2172794 \\
(0.2298763)\end{array}$ & $\begin{array}{l}0.7859172 \\
(0.1753496)^{* * *}\end{array}$ \\
\hline 2-lag Interest rate spread & $\begin{array}{l}-1.118747 \\
(0.2958315)^{* * *}\end{array}$ & $\begin{array}{l}-0.4138688 \\
(0.2114102)\end{array}$ & $\begin{array}{l}-0.9239814 \\
(0.2082057)^{* * *}\end{array}$ \\
\hline No. of observations & 167 & 91 & 258 \\
\hline No. of groups & 17 & 10 & 27 \\
\hline No. of instruments & 120 & 88 & 129 \\
\hline $\begin{array}{l}\text { Arellano-Bond test for AR(1) in first } \\
\text { differences } \\
\text { H0: There is no first-order serial } \\
\text { correlation in residuals }\end{array}$ & \begin{tabular}{|l}
-4.33 \\
$(0.000)$
\end{tabular} & $\begin{array}{l}-3.33 \\
(0.001)\end{array}$ & \begin{tabular}{|l}
-7.39 \\
$(0.000)$
\end{tabular} \\
\hline $\begin{array}{l}\text { Arellano-Bond test for } \mathrm{AR}(2) \text { in first } \\
\text { differences } \\
\text { Ho: There is no second-order serial } \\
\text { correlation in residuals }\end{array}$ & $\ldots$ & $\begin{array}{l}-1.00 \\
(0.319)\end{array}$ & $\begin{array}{l}-0.31 \\
(0.758)\end{array}$ \\
\hline $\begin{array}{l}\text { Hansen J-test of overidentifying } \\
\text { restrictions } \\
\text { H0: Model specification is correct and } \\
\text { all overidentifying restrictions (all } \\
\text { overidentified instruments) are correct } \\
\text { (exogenous) } \\
\text { (p-value in parentheses) }\end{array}$ & $\begin{array}{l}144.60 \\
(0.0028)\end{array}$ & $\begin{array}{l}89.06 \\
(0.278)\end{array}$ & $\begin{array}{l}161.22 \\
(0.0012)\end{array}$ \\
\hline $\begin{array}{l}\text { Difference-in-Hansen tests of } \\
\text { exogeneity of GMM instrument } \\
\text { subsets: } \\
\text { Hansen test excluding SGMM } \\
\text { instruments (i.e. the differenced } \\
\text { instruments) } \\
\text { H0: GMM differenced instruments are } \\
\text { exogenous }\end{array}$ & $\begin{array}{l}124.44 \\
(0.019)\end{array}$ & $\begin{array}{l}65.59 \\
(0.491)\end{array}$ & $\begin{array}{l}131.50 \\
(0.0031)\end{array}$ \\
\hline WALD test & \begin{tabular}{|l|}
6465 \\
$(0.000)$
\end{tabular} & $\begin{array}{l}3223.59 \\
(0.000)\end{array}$ & \begin{tabular}{|l|}
7219 \\
$(0.000)$
\end{tabular} \\
\hline
\end{tabular}

Source: author's calculation 
Then we wanted to find out if there is a bidirectional causal relationship of interest rate spread on public debt (Table 4). The results show that there are bidirectional causal relationships for the Eurozone and for the EU, while the model for the non-Eurozone passes the Arrelano-Bond test but does not pass the Hansen test. However, it seems that interest rate spread causes public debt, the sign depending on the lag length (positive sign in one-lag and negative sign in two-lags).

\section{CONCLUSION}

The starting idea of this paper was how to detect and measure the debt sustainability in the EU, motivated with the big increases of public spending during the crisis years and also with the situation in the EU peripheral countries that have faced the inability to further borrow in the international financial markets (due to the high level of public debt but also to its very fast growing trend). The empirical research was oriented to find out the influence of public debt on the borrowing costs (measured by long-term interest rate spreads) in the European Union. For a complex analysis of this topic we performed an analysis on different groups of countries in the EU: Eurozone and non-Eurozone, the countries most affected by the crisis (Portugal, Italy, Ireland, Greece and Spain) and new member states.

The results show that public debt has a positive and significant influence on interest rate spreads but its influence is not the same for all the observed group of countries. It varies from 5.2 and 7.7 basis points for the whole EU; 6.7 to 8.8 for the Eurozone; 0.2 to 2.9 for the non-Eurozone countries, from 4.7 to 9.1 for the group of Portugal, Italy, Ireland, Greece and Spain, and from 2.8 to 7.7 basis points for new member states. Other important variables in the explanation of the interest rate spread are inflation differentials, FDI inflows (in GDP) current account deficit and GDP growth rate which significantly change depending on the observed group. Additionally, the Granger causality test indicates the bidirectional influence between public debt and interest rate spreads in the Eurozone and the EU. The obtained results are in accordance with the results of Aizenman, Jinjarak and Park (2013), in that they found public debt and inflation to be the main drivers of interest rate spreads in the post-crisis period. Regarding the value of influence, it is the highest for PIIGS countries because most of them face increasing public debt and also an unsustainable level of public debt (in Greece, Portugal, Ireland and Italy a public debt of over 120\% of GDP). 
A somewhat weaker influence of public debt on the interest rate spread is in the EU while the smallest impact is in non-Eurozone countries who have a lower level of public debt. But on the other hand, some of them faced a very high level of external debt (e.g. Hungary and Slovenia). Greenlaw et al. (2013), Kinoshita (2006), Ichiue and Shimizu (2012) and Poghosyan (2012) also confirmed the thesis about the difference of the influence in the advanced and emerging countries as Dell'Erba et al. (2013) elaborated. The novelty of this research is to mark a difference regarding the participation in economic and monetary union that differs from other researchers who usually analyse some developed countries and/or emerging economies such as: Ichiue and Shimizu (2012) - USA and Japan; Greenlaw et al. and Poghosyan (2013) - advanced countries; Dell'Erba et al. (2013) - advanced and emerging economies (but also Eurozone countries as a subset of advanced countries). We have covered the period of 2002-2013, i.e. the precrisis, crisis and post-crisis years, to see the influence of debt in the longer period. The authors who analyzed only the crisis years found the stronger influence of public debt on interest rate spread because in this period both variables were rapidly growing.

It is interesting that for the EU and the Eurozone there exists also an evident bidirectional relationship between interest rates and public debt that can lead to problems in controlling public debt growth. The EU, through Stability/Convergence Programmes, Fiscal Compact, and the Macroeconomic Imbalance Procedure, made the effort to persuade member states to sound fiscal discipline and decreasing of public debt, but the statistical data show the opposite outcome - an increased public debt level in the EU and the Eurozone (from 62 to $87 \%$ of GDP in the EU and from 69 to 91\% in the Eurozone in the period 2003-2013). Logically the interest rate spread in the Eurozone is more sensitive to the public debt regarding the fact that their members do not have their own monetary policy and central bank as the lender of the last resort.

The analysis presented here is just one approach to measuring public debt sustainability and maybe insufficient to make conclusion on this broad topic, but it gives some logical guidelines. We can just conclude that the level of public debt has a highly significant influence on the borrowing costs and that instability in countries, accompanied with the increase in public spending, can lead to very expensive loans and also to a situation of distrust and the inability to further borrow. There is no unique formula or answer as to which debt level is unsustainable (i.e. Japan), how important is the economic policy and other indicators of the internal and external economic situation 
(equilibrium). The benefits of the EU membership are, on the one hand, higher trust and protection (in many cases) of small countries whose conditions of borrowing (if they participate as standalone countries) will be much weaker because they cannot influence the interest rates, and on the other hand, the mechanism that the EU introduced during the crisis years to collect the financial funds for providing aid to countries in the situation of their inability to borrow on the financial markets.

\section{REFERENCES}

Afonso, A., Arghyrou, M. G., Kontonikas, A., The Determinants of Sovereign Bond Yield Spreads in the EMU, Working Papers Department of Economics 2012/36, ISEG - School of Economics and Management, Department of Economics, University of Lisbon, 2012.

Aizenman, J, Jinjarak, Y., Park D., Fundamentals and Sovereign Risk of Emerging Markets, NBER Working paper 18963, 2013.

Aizenman et al., What is the Risk of European Sovereign Debt Defaults? Fiscal Space, CDS and Market Pricing of Risk, "Journal of International Money and Finance", Vol. 34, pp. 37-59, 2013.

Alper, E., Forni, L., Public Debt in Advanced Economies and its Spillover Effects on Longterm Yields, IMF Working Papers 11/210, International Monetary Fund, 2011.

Arellano, M., Bover, O., Another Look at the Instrumental Variable Estimation of ErrorComponents Models, "Journal of Econometrics", 68, pp. 29-52, 1995.

Arellano, M., Bond, S., Some Tests of Specification for Panel Data: Monte Carlo Evidence and an Application to Employment Equations, "Review of Economic Studies", 58, pp. 277-297, 1991.

Aspromourgos, T., Rees, D, White, G., Public Debt Sustainability and Alternative Theories of Interest, "Cambridge Journal of Economics", 34(3), pp. 433-447, 2010.

Attinasi, M.-G., Checherita, C., Nickel C., What Explains the Surge in Euro Area Sovereign Spreads During the Financial Crisis of 2007-09?, "European Central Bank Working Paper Series", No. 1131, 2009.

Barrios, S., Iversen, P., Lewandowska, M., Setzer, R., Determinants of Intra-eurozone Bond Spreads during the Financial Crisis, „European Economy, Economic Paper“ 388, 2009.

Beirne, J., Fratzscher, M., The Pricing of Sovereign Risk and Contagion during the European Sovereign Debt Crisis, "Journal of International Money and Finance", Vol. 34, pp. 60-82, 2013.

Blundell, R., Bond, S. R., Initial Conditions and Moment Restrictions in Dynamic Panel Data Models, "Journal of Econometrics", 87, pp. 115-143, 1998.

Bond, S. R., Dynamic Panel Data Models: A Guide to Micro Data Methods and Practice, "Portuguese Economic Journal", 1, pp. 141-162, 2002.

Cecchetti, S., Mohanty, M., Zampolli. F., The Real Effects of Debt, BIS Working Papers, 352, Bank for International Settlements, 2011. 
Checherita, C., Rother, P., The Impact of High and Growing Government Debt on Economic Growth: An Empirical Investigation for the Euro Area, Working Paper Series, 1237, European Central Bank, 2010.

Choi, G.-H., Kim, M.-J., Lee, H., Assessing Sovereign Debt Strategies Under Alternative Term Structure Models, “Asia-Pacific Journal of Financial Studies”, 39(6), pp. 777-779, 2010.

Corsetti, G., The 'Original Sin' in the Eurozone, VoxEU, 2010.

Cuddington, J. C., Analyzing the Sustainability of Fiscal Deficits in Developing Countries. The World Bank: Policy Research Working Papers, 1784, available at http://econ.worldbank.org, 1996.

De Grauwe, P., The Governance of a Fragile Eurozone, Economic Policy, CEPS working documents, 2011.

Dell'Erba, S., Hausmann, R., Panizza, U., Debt Levels, Debt Composition, and Sovereign Spreads in Emerging and Advanced Economies, CID Working Paper, 263, 2013.

Domar, E., The Burden of the Debt and the National Income, "American Economic Review", Vol. 34, no. 4, pp. 798-827, 1944.

Drakšaite, A., Assessment of the Sustainability of Government Debt in a Stochastic Economy, "Intellectual Economics“, Vol. 5, no. 3(11), pp. 401-415, 2011.

Eichengreen, B., Hausmann, R., Exchange Rates and Financial Fragility, Paper presented at the symposium New Challenges for Monetary Policy, Jackson Hole, WY, August 26-28, 1999.

Engen, E. M., Hubbard, R. G., Federal Government Debt and Interest Rates, NBER Working Paper No. 10681, 2004.

Eurostat (2014), General government gross debt annual data, http://epp.eurostat.ec.europa.eu/ $\operatorname{tgm} /$ table.do tab $=$ table\&language $=$ en\&pcode $=$ teina $225($ accessed June 25,2014$)$

Faraglia, E., Marcet, A., Oikonomou, R., The Impact of Debt Levels and Debt Maturity on Inflation, "Economic Journal", 123(566), F164-F192, 2013.

Frank, N., Ley, E., On the Probabilistic Approach to Fiscal Sustainability: Structural Breaks and Non Normality. IMF Staff Papers, 56(4), pp. 742-757, 2009.

Genberg, H., Sulatarova, A., Macroeconomic Volatility, Debt Dynamics, and Sovereign Interest Rate Spreads, "Journal of International Money and Finance", 27(1), pp. 26-39, 2008 .

Greenlaw, D., Hamilton, J. D., Hooper, P., Mishkin, F. S., Crunch Time: Fiscal Crises and the Role of Monetary Policy, paper written for "U.S. Monetary Policy Forum", a conference sponsored by the University of Chicago Booth School of Business, held in New York, February 22, 2013.

Gros, D., Alcidi, C., Adjustment Difficulties and Debt Overhangs in the Eurozone Periphery, CEPS Working Documents, Brussels, 2011.

Gupta, Khanaya, L., Budget Deficits and Economic Activity in Asia, USA and Canada. Ed. Routdledge, 1992.

Holtz-Eakin, D., Estimating Vector Autoregressions with Panel Data, "Econometrica", 56, pp. 1371-1395, 1988. 
Hsiao, C., Analysis of Panel Data, Cambridge. Cambridge University Press, 2nd edition. UK, Cambridge, 2003.

Ichiue, H., and Shimizu, Y., Determinants of Long-term Yields: A Panel Data Analysis of Major Countries, Working paper, Bank of Japan, 2012.

IMF, Global Financial Stability Report, International Monetary Fund, April 2010.

Kinoshita, N., Government Debt and Long-Term Interest Rates, IMF Working Paper, WP/06/63, https://www.imf.org/external/pubs/ft/wp/2006/wp0663.pdf, 2006.

Krugman, P., Eggertsson, G., Debt, Deleveraging and the Liquidity Trap, No 1166, 2011 Meeting Papers from Society for Economic Dynamics, 2011.

Krugman, P., Financing vs. Forgiving a Debt Overhang, "Journal of Development Economics", 29, pp. 253-268, 1988.

Kumar, M. S., Woo, J., Public Debt and Growth. IMF Working Papers 10/174 International Monetary Fund, 2010.

Laubach, T., New Evidence on the Interest Rate Effects of Budget Deficits and Debt, "Journal of European Economic Association”, 7, pp. 858-85, 2009.

Neck, R., Sturm, J.-E., Sustainability of Public Debt, “Journal of Economics”, 97(1), pp. 95-96, 2009.

Pasinetti, L., The Social Burden of High Interest Rates [in:] Arestis, P., Palma, G., Sawyer, M. (eds.), Capital Controversy in Honour of Geoff Harcourt, Vol. I. Routledge, London, 1997.

Poghosyan, T., Long-Run and Short-Run Determinants of Sovereign Bond Yields in Advanced Economies, IMF Working paper, no. 271, 2012.

Rankin, N., Roffia, B., Maximum Sustainable Government Debt in the Overlapping Generations Model. CEPR Discussion Papers 2076, 1999.

Reinhart, C. M., Rogoff, K. S., Debt and Growth Revisited, VoxEU.org., 2010a.

Reinhart, C. M., Rogoff, K. S., Growth in a Time of Debt, "American Economic Review" 100(2), pp. 573-78, 2010b.

Roodman, D M., How to Do Xtabond2: An Introduction to Difference and System GMM in Stata, "Stata Journal", 9, pp. 86-136, 2009.

Roubini, N., Debt Sustainability: How to Assess Whether a Country is Insolvent. http://people.stern.nyu.edu/nroubini/papers/debtsustainability.pdf, 2001.

Snieska, V., Draksaite, A., Evaluation of Sustainability of the General Government Debt in a Small Open Economy, "Mediterranean Journal of Social Sciences MCSER Publishing Rome-Italy", Vol. 4 No 9, pp. 610-618, 2013.

Sopek, P., The Effect of the Financial Crisis on Croatia's Primary Budget Deficit and Public Debt, "Financial Theory and Practice", 33(3), pp. 273-298, 2009.

Steinkamp, S., Wetermann, F., On Creditor Seniority and Sovereign Bond Prices in Europe, CESifo Working Paper, No. 3944, 2012.

Teica, R. A., Analysis of the Public Debt Sustainability in the Economic and Monetary Union, "International Conference Emerging Markets Queries in Finance and Business, 3, pp. 1081-1087, 2012.

Telatar, E., Bolatoglu, N., Telatar, F., A New Approach on Testing the Behaviour of the Government Towards Sustainability of Fiscal Policy in a Small-Open and Politically Instable Economy, “Applied Economics Letters", 11(5), 2004. 
Uctum, M., Wickens, M., Debt and Deficit Ceilings, and Sustainability of Fiscal Policy: An Intertemporal Analysis. Oxford Bulletin of Economics and Statistics, 62, pp. 197-222, 2000.

Verbeek, M., .A Guide to Modern Econometrics. $3^{\text {rd }}$ Edition. John Wiley \& Sons, Ltd, NJ, 2008.

WIIW, Handbook of Statistics: Central, East and Southeast Europe. WIIW, 2013.

Wooldridge, J. M., Econometric Analysis of Cross Section and Panel Data; MIT Press, Cambridge, 2002.

Wyplosz, Ch., Debt Sustainability Assessment: The IMF Approach and Alternatives, HEI Working Paper No. 03/2007, 2007.

Received: September 2014, revised: September 2015 